\title{
Partocracy or Democracy: A Popperian Perspective of Democracy in Albania
}

\author{
PhD Cand. Suela Ibraimllari
}

\begin{abstract}
"If the idea of democracy is sustainable, its implementation is uncertain, " says Cister, in order to highlight the fact that, despite efforts of different societies to consolidate their democracy, the democracy as a governance system, continues to be at risk. In this context, this research paper aims to identify, argue and analyze the level of the Albanian democracy development, which is consolidating a declined democracy system, that of partocracy. To develop this discussion, we are focused on the examination and recognition of the above two systems, which in terms of Albanian democracy, put in front of each-other, two theses in the field of political philosophy, that of Karl Popper and Mauro Calise. The comparison and recognition of these philosophical theses will guide the study of Albanian model of democracy. This discussion will go through philosophical theses, based on indicators of democracy that are: pluralism, voting system and decentralization of powers.
\end{abstract}

Keywords: partocracy, "Popperian democracy", pluralism, voting system, institutional decentralization.

\section{Introduction}

Democracy and partocracy; where does the political power lie?

When we refer to systems of governance over the past century we conclude that: ". . . democracy is known as the ideal system of government: a prominent and legitimate form, which provides a political and social structure within which people can live a happy life". Dupré, B. ; 2012, pg. 24). But for the word "democracy" there are a variety of perspectives concerning its meaning, content and conditions for its implementation. These varieties of perceptions include a conceptual plan trying to understand the meaning of democracy, as well as the efforts for its implementation through different tools.

The word "democracy" was used for the first time in Ancient Greece to materialize the social relations of the time. Democracy in Greek language means: demos-people, kratos-power, so giving power to people. This concept is quite broad and serves to characterize the forms of government, political system features and to express social relations. If we refer to the logical relation between democracy and politics, we could distinguish that democracy from this perspective, is seen as a form of organization that ensures the power of majority and esteem toward minority, by creating space for free competition of political alternatives. But in fact the word 'people' raises the discussion if the word is in singular which means forms a body or is a relative plural. According to G. Sartori, " there are six possible interpretations of the concept:

People literally mean every individual

People mean an uncertain majority, a huge number of persons

People mean lower class

People are an inseparable whole, an organic whole

People are the absolute majority

People are the majority according to the principal of absolute majority. " (Sartori, G. , 1998, fq. 14-15)

These interpretations, which carry many contradictions, give meaning to the power of people, the democracy. Contemporary theorists and philosophers rely on three basic paradigms, which are:

universality or relativity of democracy; as a system of government

democracy, a process or a condition; as governing practice

democracy, as a method or as a substance and substantial result 
George Burnham writes:" If we don't take in consideration the definition of the word democracy, but the way in which the majority uses this word, we will discover that it has nothing to do with self-government". Sartori, G. , 1998, fq. 14) Democracy in this debate is related to power: the use, allocation, power control, and responsibility of those who exercise or seek to exercise it. The problem of power does not affect the right to power, but how to exercise it; the real power is on the hands of the person who exercises it. Sartori, G., 1998, fq. 20) Democratic systems generally are based on majority rules where is emphasized the transfer of power to the representatives through the electoral mechanism.

In order to give a general overview of the history of political ideas on democracy we rank some philosophers according to the criteria: How much influence should people have on the governance of their country? Among them we can mention:

Those that support the idea of a government over people: rulers have the right to use all means to maintain their power. We can mention here, Machiavelli, "all states, all powers, that have held and hold rule over men have been and are either republics or principalities. " (Machiavelli, N., 2003, pg13). He writes: "A prince should always observe the progress of his own country; his methods will always be considered honest and appreciated by all, because people of all nations are the same, they see only the appearance and the results" ... (Machiavelli, N., 2003, pg. 87. ) So, according to him, the prince stands over moral values when exercising his powers and can use corruption and random arrests when he judges them as necessary. The political power is guided by the belief that if you don't rule, someone else will do. Politics is a form of struggle for different power positions, from highest to the lowest ones, for the survival of the state and rulers.

Those who think that someone should govern for people: leaders must exercise all their power to make reality what they think is best for the society. Representatives of this idea were Plato, Hobbes, Locke, Marx etc. ...

Those who believe in a government elected by people: people should elect their political representatives who make decisions on their behalf. As representatives of this idea we can mention Aristotle, utilitarian's, Joseph A. Schumpeter, Alexis de Toqueville etc... Joseph A. Schumpeter (1883-1950) was a supporter of representative democracy. He thought that the core of democracy was that everyone (one person- one vote) must appoint their leaders through election or rejection of the parties that appear in the election process.

In the above-mentioned platform, philosophers attribute the sovereignty to people, arguing that he has the right to establish and abolish a government, because government is, as Lincoln said, "of the people, by the people, and for the people". But today the dimensions of democracy exceed the ideological meanings and are much more pragmatic.

In this framework, we can identify other forms of democracy:

Participatory democracy: in which political engagement provides valuable knowledge and experience, a political socialization. In this kind of democracy, it is important that all the members of political parties have a meaningful contribution to the elaboration of strategies and have close cooperation with the society.

Democracy and competition: according to which the only political activity of people is to choose between elites (parties) that are in competition with each other. They will rule and probably will change in the next elections, because people do not have the capacity and knowledge to become part of the treatment of complex social problems. People are easily manipulated by idealist and populist leaders who find easy solutions. Representatives of this democracy, think that, direct democracy leads to short-term, unpredictable governance.

Democracy of discussion, its supporters admit that the core of democracy is much more than to win elections, there must be a hard work on finding the right reasons that lead to agreement and compromise. Participants in this kind of democracy should explain their views, listen to others' opinions and then decide on the best argument for the benefit of the community and society.

This is the reason why modernists see democracy as a process based on some principles, admitting that the existence of a formal process is not sufficient for achieving democratic governance. This approach creates another paradigm: democracy is a way through which the majority delegates the authority to those who want to exercise some powers (defined or limited, undefined or unlimited). Based on this delegation of authority, democracy is a set of interactive processes, in which the brake mechanism balance or coordinate, continuously or periodically, the power between executives and people. To speak about the attribution of powers, mechanisms of control and demand presupposes a choice in public institutions, which includes three branches of government: legislature, executive and judiciary. 
Opinions about democracy are not always clear or identifiable. Advanced arguments are not always coherent or logical. This is obvious in the literature of political thought of the time and especially in the public debate about democracy. One of the reasons for this political and intellectual confusion comes from the fact that the word democracy is often used in different contexts belonging to three different concepts. They are:

Democracy as a process, including mechanisms, procedures and formalities from political organization to elections.

Democracy as a term or condition, that includes everything required for a given society and its political regime, including democratic processes and also democratic results.

Democracy as an output, which includes the effects of policies and practices that are accepted by the people. This result may derive from a condition or situation, and also may be the product of democratic processes.

These three concepts are not mutually excluded and are not contradictory; on the contrary, they are at the same plan. It is however important to mention that they represent three levels or three stages of democracy. "The meaning and content of the word democracy, the difference with other systems of governance, is the right of people to take part in the management of public affairs, the legitimacy of governance and governance practices." (Sartori, G., 1998, pg. 22-23)

Vienna Declaration on the Human Rights affirms that "Democracy is based on the freely expressed will of the people to determine their own political, economic, social and cultural systems and their full participation in all aspects of their lives." However, to take into account these declarations in the light of cultural and socio-political experiences of the West would be a mistake. As stated by the General Secretary of the United Nations Boutros-Ghali, in his report in 1995 in the General Assembly," democracy is not a model that should be copied, but a goal that should be achieved by all people and assimilated by all cultures. It can take many forms, according to the particular characteristics and history of each society. "

In democratic processes, the term democratization is well known and means "state of transition" of governance which renounces undemocratic practices in favor of new forms of power separations, governance practices and responsibilities toward public. Here we can mention democracies in developing countries, which are often described as protodemocracy, with arguments that it is not known the duration of the transition stage of the system.

In order to consider a society as democratic, according to the American professor Robert A. Dahl; to organize the relationship between people and political system there must be fulfilled the following requirements:

Voting equality and freedom of speech and organization. A democratic society should be characterized by a variety of views to oppose the government even by a small group.

A variety source of information.

Free and fair elections

Free vote competition, parties must fight for voters without barriers and under the same conditions.

Impact of the elected people. Bodies elected by people must have a real influence on the governance.

Thus analysis on democracy is extended in many directions which provide a clear and broader meaning of this form of government. Although democracy is traditionally divided as direct or participatory democracy, we identify that even in this division we can find subdivisions and different meanings of the concept of people-power relationship.

On the other hand, it should be highlighted that political realities, today under the name of democracy, reveal another view of the system of governance.

We could mention here partitocracy, which according to Mauro Calise, represents a political regime in which the power has its centers in leadership of political parties and not on the bodies projected by the country's constitution. Calise, M., 1994, pg. 40-48). Although parties, through their parliamentary groups, are constitutional bodies that have an important role in determining the policies of a country, partitocracy regime constitutes a serious degeneration of the democratic system. In these conditions, partitocracy is the main reason for the failure of democratic system.

It primarily affects the party system and then the state structures and the society. Partitocracy appears especially in countries with lack of rule of law institutions, particularly those that have emerged from communist totalitarian systems. 
In partitocracy, the real power is centralized in the hands of political party leaderships, who define the political orientation and have the monopoly in decision making process of the country. Partitocracy imposes politics without ideas. Supporters of such regime are simply loyal and devoted to the party leadership.

In this regime, parliament function is atrophied, because in reality it is always in front of a taken decision and cannot effectively play its constitutional role as the center of the debate and decision making process.

The government exercises its power not according to a program, but under an agreement made between the political parties, where political parties determine government policy options according to "their areas of influence. " Partitocracy Cabinet cannot provide the necessary political stability; however, it could not fail because of the no-confidence motion in parliament. In partitocracy governments are defeated from within, as a result of disagreements between the coalition parties or, in specific cases, of internal conflicts within a party.

The main characteristic of partitocracy is manifested in the control of different sectors of the public administration, justice, health, education and society. Public services suffer political pressures. The main criterion for making career is not professionalism but party affiliation. Party influence does not end with state administration. As a direct result of the administration control, this influence is spread in sectors of economy, and encourages corruption, favors connections with groups involved in organized crime.

Another characteristic of partitocracy is the fact that the electorate does not feel represented in the country governance. He cannot influence the political orientation and the nature of possible coalitions. The only attribute is to distribute its votes between political parties without being able to influence his governance. Against a hopeless electorate, stand party militants who try to gather the fruits of partitocracy.

The contradiction of these regimes, which take their meaning by referring to the manner of exercising the power, allows the philosophical discussions on a new approach that of representative democracy. Can we consider a country as democratic if it provides pluralism, which carries the exercise of political power in the function of party members or the winning coalition? What is the impact of people who vote? How should be an electoral system that provides effective representativeness of people?

Karl R. Popper and a new approach to democracy.

"Democracy was never the rule of the people, cannot be, and must not be." (Popper, K. 2011, pg. 95)

Karl Popper in his thoughts for political philosophy focuses on two key elements:

Theory of democracy as a system of governance

On the subject of freedom.

He represents a new approach to democracy by focusing on: its definition, mechanisms that ensure democratic governance.

It is wrong to claim that the boundaries of democracy are determined by the means of its definition. In reality, the meaning of democracy is indistinguishable from other forms of governance if we only refer to its definition. Thus, other forms of government like the aristocracy or monarchy, which differ from each other because the first is based on rule of the best, and the second on the rule of an individual; they do not give the clear idea whether they are "democratic" governances or not. A concrete example is the monarchy governance in the UK which reflects a model of the best democracies. This is because in democratic states and even other countries that have different forms of government, people do not exercise power. Popper says: "Wherever rule governments (and unfortunately the bureaucracy that is state employees, who hardly take the responsibility, or don't take the responsibility at all). " (Popper, Karl R, 2011, pg. 80)

Then raises the question, which would be the distinctive mechanism of democratic governance that differs from other forms of governance? According to Popper and also other researchers who advocate the theory of the democratic state, the distinctive mechanism of democratic governance is the organization of elections or abolishment of government. This mechanism strongly supports the exercise of voting rights. Popper's theory of democracy gives this idea through his view that: "... it is not important who governs, as long as the government can be changed without bleeding." (Popper, Karl R, 2011, pg. 81) 
Thus a democratic system differs from a totalitarian and dictatorial system because it provides not only the right to vote but also other governance alternatives, which make it possible to maintain the rule of law. These alternatives give the possibility to replace a previous government and provide opportunities for the individual to meet his needs and requirements. On the other hand, the reactions of the government, which is subject of a test for its efficiency toward individuals, are quiet and try to reflect the electorate feedback in order to satisfy them and attract electorate from other governance alternatives. Popper expresses these ideas through the opinion that: "Every government that we can dismiss has a strong incentive to behave in a way that people are satisfied with it. And if the government knows that people cannot get rid of it so easily, it lacks the motivation." (Popper, Karl R., 2011, pg. 81) (

We can raise the question: Is democracy itself a system of governance that ensures sustainable basis of morality?

Popper admits that the problems of our democracies are linked with moral issues, but at the same time he highlights that democracy problems belong to the theory of state and not only to the discussion of morality about them, as it happened in Greek antiquity where questions on governance were asked as follows:

Is this governance good or bad?

Who should rule?

Popper says that the basic questions which should exist in the principals of our democracies should refer, not to the rule and ruler, but to the government and public administration.

To argue his theory of democracy, Popper studied the issue of pluralism and proportional election system

Referring to pluralism, Popper points out these ideas:

The existence of political parties in a democratic system is essential.

This necessity is due to the fact that our governments are governments of political parties and not people's governments.

But this does not mean that there should be many political parties, the existence of two political parties can make a country more democratic than a country with many political parties.

Political parties, emerging as governing alternatives in a democratic country, provide better opportunities to choose from. But the existence of many political parties affects negatively elections and the democracy of a country. Popper admits that, "It is the duty of a political party to form the government or critically monitor the work of government as an opposition" (Popper, Karl R., 2011, pg. 88). According to him, "...the idea that the large number of ideologies or views should be reflected in a large number of parties... is politically wrong." (Popper, Karl R., 2011, pg. 88).

The pluralism problem becomes even more profound when a democratic state applies the proportional election system.

Referring to this system, Popper emphasizes that the problem lies in its practical applications for the formation or fail of a government. In the context of this idea he distinguishes that:

The existence of many political parties and the implementation of a proportional electoral system make it difficult to establish a government with a single ideology and its own program, because the proportional system provides opportunities to small parties to exert a major influence on the formation of a governing majority.

The same situation is created for the abolition of a government through the voting process because the ruling majority is based on pre electoral and post-election coalitions of political parties. This means that although it may happen that in other elections is asked a government collapse; through coalitions and alliances with smaller parties, it could regain a majority although this majority "may be thousands of miles away from representing "people's will" (Popper, Karl R. , 2011, pg. 85)

But proportional system has many other problems. A key question is that of responsibility in governance. Who bears the responsibility of political decisions, when the government emerges from elections on a proportional system? When government is created from coalitions, the responsibility of political decisions is not taken by any of the coalition parties. On the other hand, according to proportional system each party chooses its representatives based on the percentage of votes. Deputies are elected as representatives of political parties, so they are obedient soldiers to them. Popper says that the depute: "...cannot be obliged by circumstances to vote against his party: It is the contrary, he is morally related to his party, 
as he is elected as representative of the party. And if in the long term it does not comply with his conscience, he would have probably the moral duty to resign, even when the constitution does not provide it) ". Popper, Karl R. , 2011, pg. 83)

Popper through his criticism toward proportional electoral system and pluralism gives the idea that the two-party system is more democratic, it enables:

The creation of a real majority in parliament.

Party self-criticism.

Implementation of radical reforms within the party when it loses in elections.

The real competitiveness with each other.

The improvement of political parties in function of the real representation of the people.

But the basis of democratic governments is referring to freedom and its limits. According to Popper "An excess of power leads to robbery. But it also exists an excess of freedom. And unfortunately there is a misuse of freedom..." (Popper, Karl R., 2011, pg. 103). Thus Popper develops four freedom theses:

Western democracies offer the best possible political systems, but institutions always need to be criticized, referring to freedom and its limits.

Democracy and freedom provide the impact of our personal ability and knowledge on the welfare of the state.

Political freedom is a freedom that represents a final value and for this reason we are not allowed to choose it.

Faith in freedom and democracy does not always provide victory, but it also leads to world disasters and degeneration to terrorism.

Through reflection on postmodern political philosophy, now let's focus on Albania and its democracy during the postcommunist period. Are we dealing with democracy as a developing process or partitocracy regime?

Albanian democracy, pluralism and proportional electoral system

Frederic Mayor when referring to democracy, points out that democracy is practice. Although based on the values that can be transmitted, the mode of action is essential. We reflect by implementing; we give legitimacy by acting.

In this context, the forms of democracy in Central and Eastern Europe are presented by different researchers in the form of a procedural democracy, which is based on a system of free elections, fair and honest that ensure civil liberties; or substantive democracy, which provides a continuous process of reproduction of regulations and relationships between government and society and its influence on governance. While the Albanian democracy is described as a protodemocracy, according to Daniel Nelson it represents, "Political systems in which there is a parliament, political parties and elections, as well as vestiges of representative government, like free and fair elections, fair judicial procedure, transparency of public discussion through independent media and other democratic principles. At the same time these are systems in which public attitudes do not reflect the norms of equal opportunities, tolerance or public accountability that citizens expect to be implemented in democracy. " (Biberaj, E. , 2011, pg. 26)

The representative system of Albanian democracy is still in transition, not only in establishing the system but also in its function. A picture of achievements of Albanian democracy is presented by Freedom House for the period 2007-2016, by ranking the indicators from the minimal level 0 (zero) to the maximum level 7 (seven). These indicators have pointed out that democracy development indicators in Albania remained unchanged and the level of democracy, according to this report is estimated worse than it was in 2007. 


\begin{tabular}{|c|c|c|c|c|c|c|c|c|c|c|}
\hline & & Nations & The & se & and $A$ & ageds & ores & & & \\
\hline & ڤ્సે & $\stackrel{\infty}{0}$ & ઠ્సે & 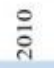 & $\overline{\frac{4}{4}}$ & $\frac{4}{2}$ & $\frac{m}{2}$ & $\frac{4}{4}$ & $\frac{n}{i}$ & 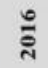 \\
\hline $\begin{array}{l}\text { National Democratic } \\
\text { Governance }\end{array}$ & 4.25 & 4.25 & 4.25 & 4.50 & 4.75 & 4.75 & 5.00 & 4.75 & 4.50 & 4.50 \\
\hline Electoral Process & 4.00 & 4.00 & 3.75 & 3.75 & 4.00 & 4.25 & 4.25 & 4.00 & 4.00 & 3.75 \\
\hline Civil Society & 3.00 & 3.00 & 3.00 & 3.00 & 3.00 & 3.00 & 3.00 & 3.00 & 3.00 & 3.00 \\
\hline Independent Media & 3.75 & 3.75 & 3.75 & 4.00 & 4,00 & 4.00 & 4.00 & 4.00 & 4.00 & 4.25 \\
\hline $\begin{array}{l}\text { Local Democratic } \\
\text { Governance }\end{array}$ & 2.75 & 2.75 & 2.75 & 3.00 & 3.25 & 3.25 & 3.50 & 3.50 & 3.50 & 3.50 \\
\hline $\begin{array}{l}\text { Judicial Framework } \\
\text { and Independence }\end{array}$ & 4.00 & 4.00 & 4.25 & 4.25 & 4.25 & 4.75 & 4.75 & 4.75 & 4.75 & 4.75 \\
\hline Corruption & 5.00 & 5.00 & 5.00 & 5.00 & 5.00 & 5.00 & 5.25 & 5.25 & 5.25 & 5.25 \\
\hline Democracy Score & 3.82 & 3.82 & 3.82 & 3.93 & 4.04 & 4.14 & 4.25 & 4.18 & 4.14 & 4.14 \\
\hline
\end{tabular}

Source: This table contains statistical data taken from the Freedom House report about the indicators of democratic development in Albania during 2007-2016.

Let's stop now, mainly on the analysis of two factors related to each other inevitably, and in the meaning of democracy as practice they are key indicators; as they are also main transformation indicators of these systems in different regimes of democracy: pluralism and electoral system. These indicators remain essential in the analysis of control and exercise of political power. Based on political and historical findings, our system is like the Italian party system. It is characterized by a stable form of multi-party system, founded on unstable political equilibrium. Its visible shortcomings are: lack of governing alternative, limitation of voter representation, instability of governments. On the other hand, the adoption of a proportional electoral law has produced a pluralist system characterized by multiplication of extreme poles and centrifugal competition of political parties, which stimulates the existence of a large number of parties and united poles in a broad ideological distance, which lead to lack of representation, government instability and inefficiency. The centripetal competition identifies a limited number of parties, which reduce ideological distance and favors representation, and political stability of governments.

The issue of pluralism in Albania, although sanctioned in the Article 9 of the Albanian Constitution, points out many polemics which are oriented in:

The existence of duopoly, as governance alternative. There are about 114 registered political parties, but in fact there are only two, the rest are unknown parties, described by some scholars as "ghost party".

Lack of concepts that refer to the identity of political parties and governing coalitions. The undefined features of political parties in government, sacrificing their identity, is a consequence of the development of Albanian society and the increasing demands toward political representatives and realization of democratic principles; but also the impact of international European forces and global politics. It should be emphasized that they do not choose a physiognomy in a pragmatic way. Indicating that "it is more difficult to exercise than to take the power" (Baladyr, E. 2007, p. 25), the idealistic programs become democratic and non-democratic platforms.

Lack of a strategic reformist vision. What confuses the issue of real representation of the people through political parties is the creation of electoral coalitions, which are defined in the Article 65, paragraph 1 and 2 of the current Electoral Code. This electoral code does not exclude the possibility of creating coalitions among parties with different programs. Problems become even more acute when the number of deputies from coalitions of the biggest political parties is equal; here appears a "small party", which holds the number of deputies that would give the majority to a coalition. History has shown that postelection alliances, in order to gain the majority in parliament, have provided links between parties with different identities. And of course the problem of representation confuses the division between position and opposition who try to take majority and lose their identity within the alliance. 
We can affirm that fragmentation, which has influenced the electoral extension and the growing number of political parties, has brought crisis of political parties and their mediation function by transforming radically the Albanian context, in particular the relationship between society and public institutions. Rousseau thought that representative systems are not really democratic because "people are free only once every few years at election time; then they return to their previous position of submission to the rules, this is not better than slavery " (Beetham, D. ; Boyle, K. 1995, pg. 7). From the ideological point of view, Albanian political system is a state of law. But if we refer to the analysis of institutional relations, the legal aspect doesn't lead these relationships or keeps the balance between the political parties. Partisanship appears in the creation and function of institutions after every electoral process, which makes people distrustful toward institutions with new staff. About this issue Rexhep Qosja said in 1997 that: "Even today like yesterday the partisanship could lead you forward, when you deserve it or not. . . it can make you rich, but this partisanship can draw you out of work and leave without any living conditions, "( Qosja, R. , 1997, fq. 64)

The scholar Artan Fuga expressed a moderate view in 2008, when stated that:

"... these institutions have two levels: first, European, Western, based in law, and an expression of the general will, and the second a simple substrate of relations between parties, which is closely linked with the local Albanian context, with the tradition of overlapping powerful social actors, in this case of parties before the law" (Fuga, A. , 2008, pg. 87). Thus we get an overview of the situation where law and institutions are seen as formal aspects of democracy, and on the other hand on the bases of this democracy is reflected an institutional function, focused on party militancy.

Subsequently, the representative of the Socialist Party, Gramos Ruçi, on a TV program entitled "Debate" in April 6, 2012 declared that " Today institutions are ruined", and at the same view was Prof. Lisien Bashshkurti, who highlighted a denatured crisis which came as a result of the financial crisis that was nothing else but the crisis in education and culture and the collapse of public administration. Institutions that have reflected such problems and have doubted the decentralization of powers such as media, General Prosecutor, the President, the Electoral College, Judicial power at all levels, public administration, but also civil society actors, reflect their lack of consolidation as a result of destabilizing processes under the influence of the ruling party, this according to the Freedom House report (Table 1). This contestation, for Albanian constitutionalists, in the context of justice reform, and the law of Veting, appears in the light of the lack of decentralization of powers, as the legislative and executive powers are hold by the same people. According to them there is an open struggle between the judiciary and the other two powers that have under control all public institutions.

On the other hand, sanctioning of a proportional electoral system is characterized by the emergence of problems about political power and that of representation of the people, this places Albanian democracy in a continuous transition. The proportional system is based on the principle according to which seats in parliament are divided in proportion with votes of political parties. In this way, Parliament is a kind of political mirror representing different political directions. Every minority and every political direction is well represented in parliament. The proportional system of elections makes it possible the establishment of new parties, because for their representation in parliament they need to win only a vote in each constituency, as they are calculated together, for example if a new party win one percent of the votes it gives the possibility to have some seats in parliament. The attraction for establishing new parties brings new elements and encourages ramification of parties and of other groups of interest. For this reason, the proportional election system often creates a parliament divided in many parliamentary groups, from which emerge unstable coalition governments with weaknesses in leadership and crises. On the other hand, on a proportional system candidates for deputy are determined in local or regional conventions, not by local party committees, which give greater influence to party leaders. This makes voters not to elect the respective candidate, but must vote for the list of relevant parties, within which candidates are ranked according to a certain row.

For this purpose, Judith Hoffman wrote that: "...Albania had and still has problems on holding elections according to international standards-despite the great support of the international community and continuously growing requirements in accordance with international standards of EU, OSCE and others. Although the development of fair elections is an essential criterion of a consolidated democracy, electoral reform is one of the most competitive and disputed part of political system in Albania. I'm afraid to say that in this respect, the Albanian democracy is a "zero sum game" and yet operates according to a logic that "the winner takes it all", which prevents decisive steps to change" (Institute of International Studies, 2011, pg. 18) 
Data on the development and consolidation of regional proportional electoral system in Albania, in the organization of elections, the implementation of election campaigns, and post-election political coalitions are identified clearly in the OSCE ODIHR reports. If we refer to the elections of June 23, 2013 we will identify that repeatedly as in the elections of 2009, appear these problems:

An atmosphere of mistrust between the two main political parties, which violated the electoral climate and created problems in the management of the electoral process.

Although the Electoral Code was amended extensively in July 2012, which improved in general the electoral framework taking into account a number of previous recommendations of OSCE / ODIHR and the Commission for Democracy through Law of the Council of Europe (Venice Commission), public confidence in the electoral process was harmed, because not all stakeholders fully implemented some important aspects.

In the absence of a decision taken by the Central Election Commission (CEC) for determining the number of deputies in four election districts, the previous Parliament decision on this matter influenced the principle of a correct process and equality of vote, due to the use of old statistics of population.

The impression that CEC acted politically, was reinforced by its decision to change the composition of election commissions at lower levels by replacing all the members of 89 Commissions of Electoral Administration Areas (CEAA) appointed by the second greatest opposition party and this decision lacked a legal argument.

In general, there was confidence in the quality of voter lists, with some concerns expressed mainly by smaller political parties, although 139 mayors and head of communes were fined for not fully performing their duties to inform the CEC about the number of voters and locations.

A variety of activities were accompanied by official government advertising campaign of the ruling party, by diminishing the boundaries between public institutions and party interests, and not respecting the paragraph 5.4 of the Copenhagen Document of the OSCE in 1990.

The pressure on public sector employees to campaign or to vote in a certain way as well as politically motivated dismissals stained the campaign. Accusations of vote buying were intensified with the approach of Election Day, and the police made several arrests.

Political parties could finance their election campaigns with contributions from public funds, private donations and loans, while independent candidates were not entitled to benefit from public funds. But the legal framework does not provide sufficient transparency about campaign finance reporting, since it is not obligatory to make known the funding before Election Day.

Audiovisual media generally offered enough time to major political parties, by creating the opportunity to inform voters about the main political attitudes. However, editorial independence was hampered by political influence. The CEC adopted a controversial decision that meant establishing an obligation to the media to broadcast materials prepared by electoral subjects, which would violate editorial freedom. The public broadcaster provided to the biggest parties the same time in news, but had a more positive tone against the ruling party. Media monitored by EOM and OSCE / ODIHR did not fulfill their obligations to provide to smaller parties specified amount of coverage in news and exceeded the limit of paid political advertising for the two major parties. The delayed creation of Media Monitoring Board and the lack of collegiality reduced its effectiveness. CEC does not effectively enforce legal regulations concerning the media.

Women candidates had low media coverage reflecting the issue of women's participation in political life. Gender quota obligation was not fulfilled by the DP, SP and the Socialist Movement for Integration (LSI) in a number of constituencies, which led to the imposition of fines, but nevertheless the candidate lists were approved. While political parties fulfilled the legal obligation to allocate at least 30 percent of each gender in the composition of CEAZ, observers noted that the women presence in Voting Center Commissions was 14 percent.

Electoral actors didn't have the effective juridical tools for resolving complaints about the election. In key cases, legal authorities refused to investigate and analyze complaints or exceeded their powers. In some cases, the Electoral College took administrative responsibilities and discretionary powers of the CEC. Electoral contestants rarely used the available 
mechanisms for solving their disagreements, due to their mistrust in the legal system and the fear of political deals. Voters and civil society groups were not legitimized to complain about the administrative decisions of electoral commissions.

Cases of family/group voting and application in different ways of some procedures affected negatively the overall assessment of the voting process.

The counting process was delayed in many $\mathrm{BCC}$ because of disorganization, including here the delayed nomination of vote counters and obstacles created by some vote counters proposed by the ruling party.

The presence of observers from civil society and party observers throughout the Election Day generally increased the transparency, although in some cases party observers interfered in voting or counting process.

The CEC received 40 complaints that did not accept the results of a number of constituencies, most of them pretending that political opponents took votes during counting process. Although the $\mathrm{CEC}$ with its reduced composition should not take into consideration complaints against the results, in practice it exercised this legal competence. While complaints presented by small parties were refused regularly, the CEC accepted and reviewed complaints introduced by major parties against the results in three regions (Lezha, Shkodra and Kukes), where the leading candidates had a small difference between them.

From the above analysis, the documented facts and reflections about them, we can conclude that the effort to consolidate the Albanian democracy is an effort that seems to put at the center Poppers theory of democracy; but it reflects the views of Caluse theory on partitocracy regimes.

It is clearly reflected in the fact that pluralism in Albania doesn't bring changes in the political aspect of democracy as a system that offers alternative choices between different political parties; but a governing duopoly that exercises its political power. Rotation characteristics didn't bring optional alternative between political parties, but ruling coalition where political parties lose their ideological identity, and didn't find similarity or common features in their programs.

In the interest of political parties are organized and function public administration and institutions. The selective criteria of employment in these institutions is not professionalism but political affiliation; a criteria that is supported and protected by militancy.

On the other hand, this kind of political and institutional pluralism was favored by proportional electoral system. The lack of elected candidates directly by people brought the leaderships of political parties to elaborate the lists of those who will be included in the election electoral system and will exercise political power. De jure this is a popperian method of establishing a representative democracy, but de facto this is a method that implies the exercise of power by the political hierarchy even within political parties, which aim to control the people, will through their representatives.

\section{Reference:}

[1] Popper, K. R. : Mendime për historinë dhe politikën, Plejad, Tiranë 2011.

[2] Calise, M. : Dopo la partitocrazia, Torino, 1994.

[3] Kushtetuta e Shqipërisë, (Tiranë 2009.

[4] Kodi Zgjedhor i Republikës së Shqipërisë, Tiranë 2011.

[5] OSBE-ODIHR: (Raporti Përfundimtar i Misionit të OSBE/ODIHR-it për Vëzhgimin e Zgjedhjeve Parlamentare, 23 qershor 2013.

[6] Dupré, B. : 50 ide politike, Plejad, Tiranë, 2012.

[7] Biberaj, E. : Shqipëria në Tranzicion (Rruga e vështirë drejt demokracisë 1990-2010), Instituti i Studimeve Ndërkombëtare, Tiranë 2011 
[8] Baladyr, E. : Makiaveli në demokraci, Eugen, Tiranë 2007.

[9] Instituti i Studimeve Europiane: Shqipëria njëzet vjet pas rënies së komunizmit; Reflektime për shtetin dhe demiokracinë, Tiranë 2011.

[10] Betham, D. ; Boyle K. : Demokracia, 80 pyetje e përgjigje, Shtëpia botuese "MNS", Tiranë.

[11] Sartori, G. : Ç'është demokracia, Dituria, Tiranë 1998.

[12] Qosja, R. : Fjalor Demokratik, Botimet Toena, Tiranë 1997

[13] Fuga, Artan: Brirët e Dhisë, Ora, Tiranë 2008.

[14] Machiavelli, N. : Princi, UEGEN, Tiranë 2003

[15] Sefa, B. ; Gjipali, G. ; Hoxha, B. : Manual Informativ mbi Institucionet Shqiptare, FLESH, Tiranë 2010.

[16] Lewis, P. G. : Political parties in Post-communist Eastern Europe, Routledge, 2000.

[17] Dyrmishi, A. : Albanian political parties and elections since 1991, Tiranë 2009. 